\title{
Spiritual treasures in Finnish art
}

DOI: https://doi.org/10.30664/ar.99492

(c)(1) Attribution 4.0 International (CC BY 4.0)

\section{Spiritual Treasures: Esotericism in the Finnish Art World 1890-1950, eds. Nina Kokkinen and Lotta Nylund (Helsinki: Parvs, 2020), 192 pp.}

Following the explosive interest in art and Western esotericism, in part a result of the discovery of the Swedish occult painter Hilma af Klint, a large number of books and catalogues have been released on the subject. While there is still fairly little research on the manifestations of esoteric ideas in Scandinavian artistic milieus, Finnish scholars have in recent years come to the forefront in the study of how fin-de-siecle occultism affected national painters, and intersected with dominant currents such as romanticism, folklore traditions, and nationalism. Spiritual Treasures: Esotericism in the Finnish Art World 1890-1950 is a valuable addition to this growing interest, as another example of the vital role esotericism played in Finnish art history and in the Nordic region as a whole.

Edited by the art historian Nina Kokkinen and chief curator Lotta Nylund, Spiritual Treasures was produced in conjunction with the exhibition entitled The Path to Hidden Knowledge, which took place at the Villa Gyllenberg Museum in Helsinki,

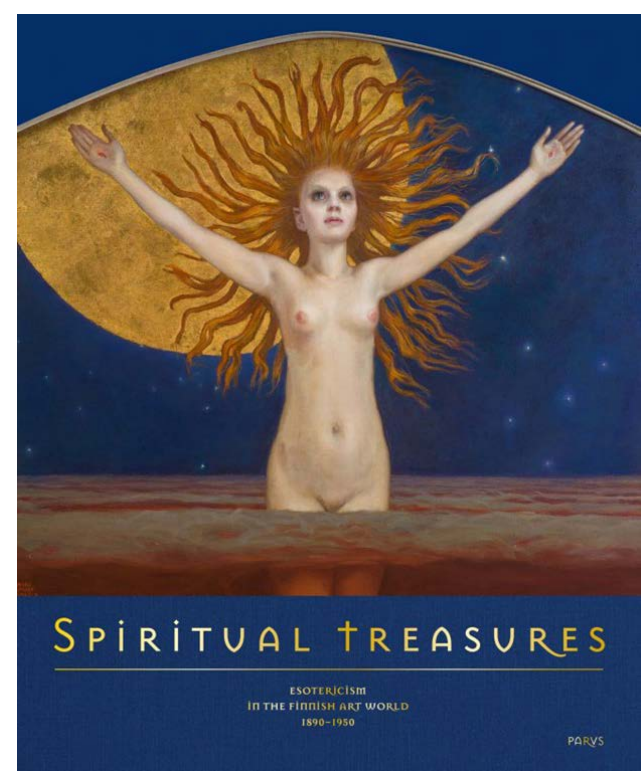

Finland, from June to October 2020. The exhibition reflected esoteric ideas in Finnish art from 1890 to 1950 and was based on the art collection of the Finnish banker, Freemason, and Anthroposophist Ane Gyllenberg - whose home has become the Villa Gyllenberg Museum - as well as pieces from public museums and other private collectors. Since many of these works are presented in Spiritual Treasures, the book combines an exhibition catalogue with an anthology of thirteen art-historical essays by Finnish scholars. 
The book begins with Nina Kokkinen's essay 'Initiation in art and esotericism', which offers important reflections on how the theme of initiation was adopted within fin de siècle artistic milieus. Initiation, a popular narrative among modern occult groups to frame higher knowledge, had become a widespread motif in esotericintellectual circles, including painters with occult interests. So was the case also in Finnish art, and as Kokkinen contextualises this influence, she guides the reader through the iconography of Finnish painters. While artists conceptualized their spiritual development in terms of initiation, features of initiation could work as a visual motif, or the artwork itself be an initiation to divine insight. Kokkinen's typology of initiation clearly explains its central symbols and ideas, while being illuminating on how they were interpreted among artists.

In the essays that follow, Spiritual Treasures explores mainly three themes: the general Anthroposophical influence upon art, reoccurring esoteric motifs in Finnish art and especially in the collection of Signe and Ane Gyllenberg's foundation, and the historical context of Finnish esoteric painters. The latter theme is the most rewarding one. For example, Riikka Stewen's 'Orpheus as an artist: Magnus Enckell and Péladan's Salon Rose+Croix' directs attention to the French occultists, especially their leader, the famous writer and art critic Joséphin Péladan. They influenced Finnish painters who lived and worked in 1890 os Paris and who not only found inspiration in Péladan's idea of art as the new religion, but also had the opportunity to exhibit at his Salon de la Rose+Croix and later used it as a model for their own exhibitions in Finland. Although the essay only offers a brief account of this, it confirms the importance of international influences in the development of occultism in the Nordic countries.
A similar story is told in Marja Lahelma's 'Art about life and death: spirituality and esotericism in the art of Helene Schjerfbeck and Ellen Thesleff'. Lahelma assesses two female artists who rose to the forefront of Finnish Modernism in the 1920s, but who had worked together in Florence in 1894 inspired by the idealization of Renaissance art and spirituality. Neither Schjerfbeck nor Thesleff joined any of the popular esoteric movements of the time, but instead drew from a wide range of sources including the writings of Plato and Catholic mysticism. Although artworks from this period did not deal overtly with esoteric themes, Lahelma's analysis successfully explains an underlying air of spirituality that preceded the two artists' more renowned modernist works.

Finally, the second essay by Kokkinen is also well worth mentioning. 'Ilona Harima and mediumistic art' is particularly interesting, as it presents another type of esoteric art not defined by motifs in paintings or the artist's association with occult networks. Instead, the influence concerns the method of artistic production itself. Starting from the mid-nineteenth century and onwards, some artists began producing art through the mediumistic techniques derived from the Spiritualist movement. It was common for a Spiritualist medium to speak and write under the direct influence of spirits, as if the spirits themselves were communicating through him or her. As painters adopted this method into their work, they introduced what is today termed 'mediumistic art' - art produced under the influence of a spirit who is perceived by the artists to be the real author of the image. For acclaimed painters Hilma af Klint and Georgiana Houghton, such methods gave rise to a radical art that opposed conventions. Whether this applies to the Finnish painter and Theosophist Ilona Harima, whose work 
is more modest in style, remains up for debate. Nevertheless, Harima is another example of such an influence as she regularly experienced a spirit taking possession of her body to produce figurative paintings inspired by Buddhist and other themes from Asian art - paintings that were rarely exhibited or sold. Although mediumistic artists display some common traits, for example in terms of gender and class, there is still a lot to understand about this phenomenon through scholarly investigation. In this respect, Kokkinen's case study aptly explains such a polysemous subject.

Because Spiritual Treasures intends to reach outside the narrow framework of the study of Western esotericism and appeal to a general interest in art and spirituality, it requires that a complex topic be made accessible to a wider range of readers. Although this objective is accomplished, the book employs a conceptual framework that does not successfully explain esoteric ideas and currents. While the common definition of Western esotericism is formulated as a pursuit of - or discourse about - rejected or hidden knowledge, Spiritual Treasures introduces it as historical currents that are based on initiation in which 'masters' are passing down hidden knowledge to 'adepts' (pp. 6, 8). Since the book covers a wide variety of notions, the majority of which do not fall within the parameters of initiation, lay readers will probably find themselves confused as to how Western esotericism, in fact, relates to the various themes presented in the essays. Spiritual Treasures could instead have employed a broader historical introduction to Western esotericism which made its complex nature understandable to a wider audience, as well as better explained its particular development within fin-de-siècle culture. Despite this drawback, Spiritual Treasures remains an enlightening contribution to the discourse on esotericism and art that explores the occult roots of artistic creativity. It will appeal to experts and amateurs alike who wish to gain knowledge of the role these ideas had in modern Finnish art history and, ultimately, the Nordic region as a whole.

\section{Hedvig Martin}

Hedvig Martin is a doctoral candidate in Western esotericism at the Centre for Hermetic Philosophy and Related Currents at the University of Amsterdam. 